УДК 159.992

doi: 10.15330/ps.10.1.132-139

Наталія Добровольська

Східноукраїнський національний університет імені Володимира Даля

dobro73@ukr.net

\title{
СИСТЕМНО-ІНТЕГРОВАНИЙ ПІДХІД ДО ПРОБЛЕМИ ОБДАРОВАНОСТІ ОСОБИСТОСТІ НА РІЗНИХ ЕТАПАХ ЇЇ ОНТОГЕНЕЗУ
}

У статті розкрито можливості застосування системно-інтегрованого підходу до вивчення проблеми обдарованості особистості на різних етапах ї̈ онтогенезу. Зокрема з позицій системноінтегрованого підходу виявлено загальну структуру психорегулячійних компонентів обдарованої особистості. Розглянуто структуру сочіально-психологічних проявів обдарованої особистості $i$ визначено їх внесок у загальну регуляцію навчальної діяльності; виявлено ієрархію домінантних цінностей $і$ мотивів обдарованих підлітків і визначено типологію обдарованих дітей з розкриттям змістовних $і$ структурних характеристик кожного з типів; сформульовано психодіагностичні критерії особистісних характеристик, які сприяють регуляиії навчальної діяльності і показано значущість изіннісних орієнтацій для оптимального розкриття здібностей обдарованих учнів; розроблено спеціальну програму соціально-психологічного супроводу процесу становлення обдарованої особистості. Індивідуальні відмінності компонентів психічної регуляиії навчальної діяльності дозволили виокремити групу обдарованих респондентів з продуктивною мотивачійною складовою психічної регулячії такої діяльності та досліджуваних з непродуктивною мотиваційною складовою психічної регулячії навчальної діяльності. Показано, щуо реалізація системного підходу в иій галузі вимагає не тільки реконструкції наявних концепцій обдарованості, а й розробки нових технологічних рімень - комплексу засобів, здатних фіксувати досліджуваний предмет як багатовимірний, цілісний $і$ змінюваний у часі, зокрема залежно від різних умов навчання. Програма соціально-психологічного супроводу, побудована на принципах системно-інтегрованого підходу та спрямована на становлення мотивачійної складової механізму психічної регулячії навчальної діяльності обдарованої особистості, довела свою ефективність у напрямку підвищення показників творчої мотивачії, творчої спрямованості, рефлексивності, здатності до комбінування, дивергентного мислення, свободи продукування асоиіацій, винахідлиості, самооцінки, саморегулячіï.

Ключові слова: особистість, онтогенез, обдарованість, структура обдарованості, системноінтегрований підхід.

Постановка проблеми. Стрімкий розвиток суспільства сприяє змінам в царині економічного та культурного життя, науки і техніки. Одна з актуальних проблем сучасного суспільства - формування особистості, здатної не лише жити в мінливих соціальних і економічних умовах, а й активно та конструктивно впливати на сьогодення. На перший план виходять певні вимоги до такої особистості - творчої, активної, соціально відповідальної, яка має добре розвинений інтелект, високоосвіченої, професійно грамотної. У зв'язку з цим проблема вивчення обдарованої особистості визначається, з одного боку, сучасними уявленнями про складність і багатовимірність структури обдарованості і різноманітності чинників, які визначають іiі розвиток протягом життєвого шляху, а 3 іншого боку, - необхідністю створення умов, що забезпечують реалізацію ії потенційних можливостей. При цьому особливу увагу привертає реалізація здібностей обдарованих дітей у своєму майбутньому житті $[10 ; 11]$.

Відомо, що ранній прояв і виявлення обдарованості не гарантує збереження іï на більш пізніх етапах розвитку особистості. Причинами цього явища можуть бути вирівнювання прискореного темпу розвитку дитини на етапі статевого дозрівання, незадоволеність наявною системою навчання і виховання, напружені стосунки з однолітками і вчителями, викликані нестандартністю поведінки й емоційними спалахами. Це може призводити до того, що всі свої сили обдарована дитина буде витрачати на боротьбу і протистояння, а не на роботу і творчість, що у підсумку негативно позначиться на продуктивності їі діяльності $[1 ; 2 ; 7 ; 8 ; 10]$.

Зазначене обумовлює необхідність вивчення проблеми обдарованості особистості на різних етапах іiї онтогенезу з позицій методології системно-інтегрованого підходу. 
Мета дослідження - розкрити особливості запровадження системно-інтегрованого підходу до вивчення проблеми обдарованості особистості на різних етапах її онтогенезу.

Аналіз останніх публікацій з проблеми обдарованості показав, що найбільш складним питанням в розумінні й оцінці проявів обдарованості у дитинстві є взаємодія вікових і соціально-психологічних особливостей. Зокрема, як зазначає Н. Лейтес [9], у процесі онтогенезу дитини вікові риси є водночас і властивостями розуму, що розвивається. I в цьому разі доречно говорити про вікові фактори обдарованості. Найважливіші завдання побачити в ознаках обдарованості дітей те, що належить до властивостей віку і $є$ тимчасовим, і те більш стійке, власне індивідуальне, що має вкоренитися, розвинутися.

Як слушно зазначає О. Ткаченко [11], рівень і своєрідність розумового і творчого потенціалу в період дитинства найбільш яскраво проявляється на вікових переломах, коли на перший план виступають власне індивідуальні, міжвікові властивості, які будуть сприяти особистісному зростанню. У зв'язку з цим період пубертату може вважатися досить сприятливим етапом онтогенезу особистості щодо виявлення іiї обдарованості.

Вчені наголошують, що всебічний гармонійний розвиток особистості має спиратися на реальні закони розвитку дитини, механізми їх використання у психолого-педагогічному процесі, адже саме у дитячому віці закладається фундамент особистості, інтенсивно формуються базові соціальні установки, основи світогляду, звички, розвиваються пізнавальні здібності, емоційно-вольова сфера, складаються різноманітні взаємини 3 навколишнім світом (Б. Ананьєв, Л. Божович, Л. Виготський, В. Давидов, Д. Ельконін, Л. Занков, 3. Карпенко, В. Мухіна, Л. Обухова та ін.).

Величезну роль у розвитку дитини відіграє період шкільного навчання. Важливо, щоб саме у школі складалися умови, які сприяють різнобічному розвитку дитини, формуванню вміння відкрито висловлювати свої почуття і думки. Важливу роль в освіті виконують засоби, що сприяють зіставленню, порівнянню, виділенню головного, а в підсумку орієнтації і випереджувальній адаптації неповнолітніх до життя в умовах сучасного соціуму і становленню активної життєвої позиції. Формування соціально відповідальної поведінки, вироблення системи цінностей як орієнтирів власної поведінки найбільш значущі в підлітковому віці, що характеризується переходом від дитинства до дорослості, пошуком особистісної ідентичності [3; 4; 5].

Нагадаємо, що одне 3 найважливіших положень психології обдарованості полягає в тому, що розвиток обдарованості не може розглядатися поза взаємодією особистості, яка розвивається, і їі соціального оточення (А. Брушлинський, К. Хеллер). Спроби зрозуміти і відобразити ці взаємодії представлені у низці моделей обдарованості (Дж. Рензуллі, К. Хеллер та ін.). При цьому підкреслюється особлива роль шкільного навчання у створенні умов, орієнтованих на особливі можливості обдарованих дітей. Для створення таких умов необхідним $є$ розвиток методів виявлення цих особливостей при різних проявах обдарованості, простеження їх змін у ході вікового розвитку залежно від умов виховання і навчання, допомоги обдарованій особистості у вирішенні ії проблем [10].

На сучасному етапі розвитку науки вчені-психологи відзначають значення мотиваційних та емоційно-вольових характеристик, інтересів, Я-концепції та інших особистісних особливостей у розвитку обдарованості і навіть включають ці чинники безпосередньо в ії структуру (Дж. Фрімен, Х. Хекхаузен, К. Хеллер). Експериментальні дані показують взаємозв'язок цих факторів з успішністю навчальної діяльності, і хоча механізм цього взаємозв'язку на різних вікових етапах багато в чому залишається нез'ясованим, дослідження показали можливість позитивного впливу на когнітивний розвиток обдарованої особистості через підвищення іï самооцінки та зміни мотивації досягнення (Б. Термен, О. Ткаченко, К. Хеллер) [11].

Аналіз наукової і науково-практичної літератури виявив недостатню кількість даних про структуру особистості обдарованої особистості, зокрема, про складові психічної регуляції навчальної діяльності у підлітковому віці. У роботах К. Абульханової-Славської, О. Дашкевича, В. Зобкова, О. Конопкіна, В. Чудновського розкриваються питання 
психорегуляції навчальної діяльності учнів. Разом із тим, не досліджено цілісний механізм психорегуляції навчальної діяльності обдарованого підлітка. Отже, актуальним $\epsilon$ проведення комплексних досліджень, орієнтованих на визначення місця і ролі всієї сукупності провідних чинників особистості обдарованого підлітка, що мають безпосереднє відношення до особистісного рівня психічної регуляції.

Необхідність такого дослідження пов'язана з вимогами запровадження системноінтегрованого підходу до вивчення проблеми обдарованості особистості на різних етапах iii онтогенезу з урахуванням домінантного впливу мотиваційних установок, ціннісних орієнтацій, самооцінки як системоутворювальних якостей, необхідних для розв'язанні завдань формування і становлення обдарованої особистості.

Виклад основного матеріалу. Гіпотеза дослідження полягає у припущенні про те, що особистість обдарованого підлітка представлена системою компонентів (винахідливість, здатність до комбінування, дивергентне мислення, свобода асоціацій, творча мотивація, творча спрямованість, рефлексивність, самооцінка, саморегуляція), рівень розвитку i взаємозв'язку яких впливає на успішність навчальної діяльності. Передбачається, що у компонентній структурі психорегуляції навчальної діяльності перелічені якості будуть визначальними. Вони, у свою чергу, вплинуть на ступінь вираженості таких якостей, як товариськість, чуйність, організованість, наполегливість і відповідальність. Саме від особливостей розвитку зазначених компонентів буде залежати вибір оптимальних способів, прийомів і засобів психорегуляції навчальної діяльності обдарованої особистості на цьому етапі онтогенезу.

Методологічну основу дослідження становили: системно-інтегрований підхід у психології (Б. Ананьєв, Л. Виготський, В. Давидов, З. Карпенко, С. Максименко, А. Маркова, Ю. Поваренко, С. Рубінштейн, В. Шадриков та ін.); концепції обдарованості (Д. Богоявленська, Н. Лейтес, В. Моляко, М. Смульсон, Б. Теплов, В. Шадриков та ін.); психологічні теорії особистості (Б. Ананьєв, Л. Виготський, А. Леонтьєв, В. Мясищев, К. Платонов, С. Рубінштейн та ін.); діяльнісний підхід і принцип зв'язку психічних процесів і діяльності (К. Абульханова-Славська, Д. Богоявленська, А. Брушлинський, Л. Виготський, В. Давидов, О. Леонтьєв, С. Рубінштейн та ін.); концепції психічної регуляції діяльності (В. Вілюнас, О. Дашкевич, В. Зобков, О. Конопкін, В. Моросанова, В. Чудновський та ін.).

Необхідною умовою реалізації системних уявлень про обдарованість у наукових дослідженнях обдарованої особистості є технологія психологічної діагностики, що включає систему надійних і валідних методів, здатних фіксувати досліджуваний предмет як багатовимірний, цілісний і змінюваний, що забезпечують вікову спадкоємність показників обдарованості і спрямовані на сприяння ії розвитку.

У процесі дослідження був застосований комплекс методів, за допомогою яких дані, отримані за однією методикою, перевірялися, доповнювалися, зіставлялися і коригувалися за допомогою інших методик.

Комплекс методів і прийомів аналізу (прийоми спостереження і класифікації, аналізу, узагальнення і перетворення) разом із методикою психологічного експерименту, методів статистичної обробки матеріалу послідовно поєднували аналіз і синтез, дозволяли зробити висновки на основі розгляду отриманих даних.

Методи дослідження: спостереження, в тому числі включене, аналіз результатів навчальної діяльності, експертні оцінки, соціометрія, методики вивчення якостей особистості (тест Р. Кеттелла, опитувальник В. Зобкова), психометричні методики (культурновільний тест Р. Кеттелла, який діагностує рівні розвитку абстрактного мислення, і тест П. Торранса на виявлення рівня сформованості образного творчого мислення), метод лабораторного експерименту (МР-1 О. Дашкевича), методики дослідження обдарованості (тест на виявлення творчих здібностей Х. Зіверта, методика діагностики визначення спрямованості особистості (Б. Басс)); методики дослідження соціально-психологічних властивостей особистості (методика «Стиль саморегуляції поведінки» В. Моросанової), методика діагностики індивідуальної міри розвитку рефлексивності А. Карпова та В. Понома- 
рьової, методика дослідження самооцінки (МДС) Т. Дембо і С. Рубінштейн у модифікації Г. Прихожан, методика дослідження самоставлення (МДС) С. Пантилєєва, модифікований опитувальник діагностики самоактуалізації особистості САМОАЛ (А. Лазукін в адаптації Н. Каліної), опитувальник термінальних цінностей І. Сеніна, методика вивчення ціннісних орієнтацій (опитувальник Шварца), метод формувального експерименту.

Вибір методів був обумовлений особливостями предмета і об'єкта дослідження і визначався такими критеріями: змістом параметрів, що відображають психологічні особливості, риси обдарованої особистості; можливістю кількісного представлення результатів з метою подальшої математичної обробки; можливістю підтвердження результатів дослідження за допомогою інших методик.

Запропонований комплекс методів був спрямований на вивчення об'єктивно-діяльнісних і суб' єктивно-особистісних показників. Системно-інтегрований підхід забезпечував необхідну багатоаспектність, власне системність і поліструктурність розгляду досліджуваного об'єкта.

Дані підлягали математико-статистичній обробці за допомогою методів кореляційного і факторного аналізів; достовірність відмінностей результатів визначалася за допомогою застосування t-критерію Стьюдента.

Емпіричне дослідження було здійснено в чотири етапи. У межах першого етапу було визначено проблему дослідження та ії актуальність. Він включав теоретичний аналіз, узагальнення вітчизняних і зарубіжних літературних джерел та експериментальних студій 3 проблеми дослідження. Другий етап - констатувальний. Під час реалізації цього етапу розроблено науковий апарат дослідження: визначено цілі, завдання дослідження, методи емпіричного дослідження. Результатом стала розроблена модель емпіричного дослідження. На цьому етапі реалізовано констатувальний експеримент, проаналізовано й систематизовано отримані дані. Третій етап - експериментальний. На цьому етапі реалізовано формувальний експеримент, проаналізовано й систематизовано отримані дані. На четвертому етапі здійснювалася інтерпретація отриманих даних.

Дослідження проводилося на базі загальноосвітніх шкіл Центрального, Східного та Західного регіонів України. Загальна кількість досліджуваних неповнолітніх - 56 осіб, серед них 32 дівчини та 24 хлопця, яких було розподілено на експериментальну і контрольну групи по 28 респондентів у кожній 3 них. Вибірка формувалася методом репрезентативного моделювання з урахуванням параметру мотивації респондентів.

Достовірність результатів дослідження забезпечувалася його загальнотеоретичною орієнтацією на провідні концепції вітчизняної психології, використанням комплексу методів багатоаспектного дослідження особистості, об'єктивно-психологічним аналізом діяльності, результатами використання соціально-психологічної програми формувального впливу, спрямованої на сприяння розвитку обдарованої особистості, залученням сучасних методів статистичної обробки даних.

Фундаментальне значення для здійснення такого переходу має положення Л. Виготського про психологічну систему обдарованості як єдину, але різноманітну і складно структуровану цілісність. У розробку цілісного підходу до розуміння обдарованості і $\dddot{\text { ï }}$ розвитку істотний внесок внесли С. Рубінштейн, Б. Теплов, Б. Ананьєв, Д. Богоявленська, Є. Голубєва, Н. Лейтес, С. Максименко, В. Моляко, К. Платонов, Я. Пономарьов, В. Шадриков та інші вчені.

Слід наголосити, що сучасні визначення обдарованості, незважаючи на активне використання термінів (система, системність, системний підхід) орієнтовані на їі реалізовані форми, зокрема на видатні досягнення, причому не тільки у дорослих, але і в дітей. У той же час умови процесуальної сторони цих досягнень розкриті недостатньо, а розвиток обдарованості найчастіше ототожнюється 3 динамікою ії окремих сторін, складових особистості обдарованих неповнолітніх без урахування їх взаємодії і впливу оточення. Реалізація системного підходу в цій галузі вимагає не тільки реконструкції відомих концепцій обдарованості, а й розробки нових технологічних рішень - визначення комплексу 
засобів, здатних фіксувати досліджуваний предмет як багатовимірний, цілісний і змінюваний у часі і залежно від різних умов навчання $[6 ; 7 ; 10]$.

При описі навчальної діяльності був використаний системний аналіз, який передбачає вивчення діяльності як багаторівневого поліструктурного утворення і виділені такі рівні аналізу: особистісно-мотиваційний; компонентно-цільовий (склад дій, мета, значення кожної дії в загальній структурі діяльності); структурно-функціональний (принципи організації і механізми взаємодії окремих дій в цілісній структурі діяльності); соціальнопсихологічний.

При вивченні специфіку обдарованої особистості встановлено, що обдарованість це інтегрований сплав здібностей людини і системи її особистісних якостей (мотиваційної структури, системи ціннісних орієнтацій, особливостей морально-етичної, комунікативної, емоційної, вольової, інтелектуальної сфер). Успішне здійснення навчальної діяльності можливе лише з урахуванням здібностей дитини та іiі мотивації. У зв'язку з цим проблема вивчення психорегуляційного механізму навчальної діяльності обдарованого підлітка набуває особливої практичної значущості, яка зумовлена можливістю оптимізувати процес його навчальної діяльності. Необхідний результат у роботі з обдарованими учнями може бути досягнутий внаслідок запровадження активних методів навчання і відповідного соціально-психологічного супроводу.

В ході проведеного теоретичного та практичного дослідження було вивчено механізм психічної регуляції навчальної діяльності обдарованої особистості, виявлено якісну своєрідність особистості обдарованого учня. Застосовані методики дозволили на першому етапі дослідження ідентифікувати обдарованого підлітка, а на другому етапі - виявити основні характеристики особистості обдарованого підлітка. Інформація про власне механізм психічної регуляції навчальної діяльності обдарованого підлітка була отримана за допомогою кореляційного і факторного аналізів. Вивчення структурних та змістовних компонентів психорегуляції навчальної діяльності обдарованих підлітків, їх взаємозв'язків дозволило виділити серед обдарованих підлітків різні психологічні типи з різним ступенем гармонізації мотиваційної складової психорегуляції навчальної діяльності (з продуктивною мотиваційною складовою психічної регуляції навчальної діяльності та 3 непродуктивною мотиваційною складовою психічної регуляції навчальної діяльності).

Наведені теоретичні положення були використані при організації експериментальної роботи, що включила застосування різних методів діагностики обдарованої особистості. Для забезпечення високої результативності формувального експерименту були створені експериментальна і контрольна групи. Для роботи експериментальної групи були забезпечені певні умови: психологічні, соціальні та організаційні. В ході експерименту використовувалися елементи активного навчання, соціально-психологічний тренінг, тренінг розвитку творчих здібностей тощо.

Структура психологічного механізму регуляції навчальної діяльності обдарованої особистості представлена блоками: мотиваційно-діяльнісних показників, що включає підблоки загально-діяльнісних і специфічно-діяльнісних показників; ціннісних орієнтацій (термінальні та інструментальні цінності); самооцінювальних показників, а також блоком особистісних якостей. Провідною ланкою психічної регуляції навчальної діяльності обдарованої особистості є показники мотиваційно-діяльнісного блоку і ціннісні орієнтації (самоповага, вибір свого призначення у житті, творчість, допитливість, здібності, успішність у справах), що впливають на становлення якісно своєрідного виду навчальної діяльності.

Констатовано, що існують проблеми у пристосуванні обдарованих підлітків до вимог навчальної діяльності, виражені в ігноруванні стандартних вимог і вираженою соціальною автономністю обдарованої особистості; у частковій, а іноді й повній ізоляції обдарованих учнів від їх однолітків через невідповідність прагнень і інтересів; у прагненні до досконалості і постановці завищених нереалістичних цілей, що призводить до переживань 3 приводу неможливості їх досягнення і викликає негативну оцінку з боку дорослих i однолітків. 
На підставі ступеня сформованості механізму психорегуляції навчальної діяльності були виокремлені дві групи обдарованих неповнолітніх (з продуктивною мотиваційною складовою психорегуляції навчальної діяльності, які успішно адаптуються до процесу навчання; 3 непродуктивною мотиваційною складовою психорегуляції навчальної діяльності, які мають серйозні труднощі у процесі спілкування).

Основні розвивальні та психокорекційні засоби програми соціально-психологічного супроводу обдарованих підітків були спрямовані на становлення мотиваційної складової психорегуляції їх навчальної діяльності, що істотно впливає на функціонування механізму психорегуляції і дозволяє ефективніше здійснювати навчальну діяльність.

Реалізація програми засвідчила, з одного боку, позитивні зміни у параметрах обдарованості, а з іншого - самоактуалізації особистості, гармонізації системи ставлень і самооцінок, а також підвищення рефлексивності, що коригує ії систему цінностей. У респондентів експериментальної групи відбулися значущі зміни за всіма показниками креативності найбільші за шкалами «дивергентне мислення» та «творча спрямованість», менші - за шкалою «винахідливість». Водночас у контрольній групі значущого зростання показників не відбулося (див. табл. 1, 2).

Таблиия 1

Середні значення показників розвитку обдарованості респондентів експериментальної (ЕГ) та контрольної (КГ) груп після формувального експерименту

\begin{tabular}{|l|c|c|c|c|}
\hline \multicolumn{1}{|c|}{ Показники } & $\begin{array}{c}\mathbf{E} \boldsymbol{\Gamma}(\mathbf{n = 2 8}) \\
\mathbf{M} \pm \boldsymbol{\sigma}\end{array}$ & $\begin{array}{c}\mathbf{K} \boldsymbol{\Gamma}(\mathbf{n = 2 8}) \\
\mathbf{M} \pm \boldsymbol{\sigma}\end{array}$ & $\mathbf{t}$ & $\mathbf{p}$ \\
\hline Винахідливість & $22,6 \pm 2,0$ & $17,3 \pm 1,5$ & 3,18 & $\leq 0,05$ \\
\hline Здатність до комбінування & $27,9 \pm 2,3$ & $21,2 \pm 1,6$ & 4,33 & $\leq 0,05$ \\
\hline Дивергентне мислення & $44,9 \pm 2,8$ & $35,9 \pm 3,4$ & 4,46 & $\leq 0,05$ \\
\hline Свобода асоціацій & $30,3 \pm 2,6$ & $23,4 \pm 3,2$ & 3,25 & $\leq 0,05$ \\
\hline Творча мотивація & $4,3 \pm 0,2$ & $3,7 \pm 0,3$ & 3,92 & $\leq 0,05$ \\
\hline Творча спрямованість & $31,0 \pm 1,8$ & $27,5 \pm 1,6$ & 3,26 & $\leq 0,05$ \\
\hline
\end{tabular}

Таблиия 2

Середні значення показників розвитку обдарованості респондентів експериментальної групи на констатувальному (I зріз) та формувальному (II зріз) етапах дослідження

\begin{tabular}{|l|c|c|c|c|}
\hline \multicolumn{1}{|c|}{ Показники } & $\begin{array}{c}\text { I зріз (n=28) } \\
\mathbf{M} \pm \boldsymbol{\sigma}\end{array}$ & $\begin{array}{c}\text { II зріз (n=28) } \\
\mathbf{M} \pm \boldsymbol{\sigma}\end{array}$ & $\mathbf{t}$ & $\mathbf{p}$ \\
\hline Винахідливість & $17,9 \pm 1,3$ & $23,7 \pm 2,2$ & 1,95 & $\leq 0,05$ \\
\hline Здатність до комбінування & $22,4 \pm 1,5$ & $28,4 \pm 2,5$ & 2,31 & $\leq 0,05$ \\
\hline Дивергентне мислення & $35,2 \pm 3,2$ & $46,8 \pm 2,3$ & 4,30 & $\leq 0,05$ \\
\hline Свобода асоціацій & $23,6 \pm 2,6$ & $31,1 \pm 2,2$ & 3,17 & $\leq 0,05$ \\
\hline Творча мотивація & $3,8 \pm 0,3$ & $4,5 \pm 0,3$ & 2,46 & $\leq 0,05$ \\
\hline Творча спрямованість & $26,0 \pm 1,5$ & $31,5 \pm 1,4$ & 4,39 & $\leq 0,05$ \\
\hline
\end{tabular}

Експериментальний етап дослідження показав, що відбулося підвищення ефективності навчальної діяльності обдарованих підлітків експериментальної групи у порівнянні з контрольною групою, де подібні зміни були менш значні за якістю і зайняли значно більший проміжок часу.

В результаті проведеної експериментальної роботи були зафіксовані позитивні зміни мотиваційно-діяльнісних, самооцінювальних і особистісних характеристик досліджуваних експериментальної групи, які були відсутні у респондентів контрольній групі.

Висновки. Структура механізму психічної регуляції навчальної діяльності обдарованої особистості включає у себе мотиваційно-діяльнісний блок, блок ціннісних орієнтацій, самооцінювальний блок і блок особистісних якостей. Провідна позиція у структурі психорегуляції належить показникам мотиваційно-діяльнісного блоку. Ефективність навчальної діяльності обдарованої особистості забезпечується поєднанням загальних і специфічних мотиваційно-діяльнісних показників. Особливості психорегуляційного меха- 
нізму навчальної діяльності обдарованої особистості є компонентами соціальної пристосованості/непристосованості. Індивідуальні відмінності компонентів психічної регуляції навчальної діяльності обдарованої особистості дозволили виокремити групу обдарованих респондентів з продуктивною мотиваційною складовою психічної регуляції навчальної діяльності та досліджуваних 3 непродуктивною мотиваційною складовою психічної регуляції навчальної діяльності. Програма соціально-психологічного супроводу, спрямована на становлення мотиваційної складової механізму психічної регуляції навчальної діяльності обдарованої особистості, розроблена з урахуванням показників винахідливості, здатності до комбінування, дивергентного мислення, свободи асоціацій, творчої мотивації, творчої спрямованості, рефлексивності, самооцінки, саморегуляції, довела свою дієвість в експериментальній групі респондентів.

1. Антонова, О. Є. (2005). Обдарованість: досвід історичного та порівняльного аналізу: монографія. Житомир: Житомирський державний університет імені Івана Франка.

2. Барко, В. (2000). Психолого-педагогічна діагностика творчого потенціалу особистості учня в навально-виховному прочесі. Тернопіль: ТНУ.

3. Борисюк, А. С. (2016). Психологічні передумови й чинники особистісного та професійного розвитку студентів. Чернівці: Технодрук.

4. Бриль, М. М. (2011). Вплив соціокультурного середовища на розвиток креативності студентів. Актуальні проблеми психологї, 10, 20, 22-30.

5. Волобуєва, Т. Б. (2015), Розвиток творчої компетентності. Харків: ХНУ.

6. Карпенко, 3. (2018). Аксіологічна психологія особистості: монографія. Івано-Франківськ: ДВНЗ «Прикарпатський національний університет імені Василя Стефаника».

7. Клименюк, Ю. М. (2015). Обдаровані діти, їх виявлення та діагностика. Проблеми освіти. Спецвипуск. 46-50.

8. Кульчицька, О. (2007). Методика діагностики інтелектуальної обдарованості. Обдарована дитина, $1,39-42$.

9. Лейтес, Н. С. (1997). Возрастная одаренность и индивидуальные различия. М.: Ин-т практ. психологии; Воронеж: НПО «МОДЭК».

10. Ткаченко, Е. С. (2000). К вопросу о структуре одаренности и ее характеристиках. Aктуальныле проблемы психологии, философии, этики и эстетики, 74-77.

11. Ткаченко, Е. С. (2003). Инициативность как ведущая черта личности одаренного подростка. Психология отношений и психическая регуляичи деятельности, 116-119.

\section{REFERENCES}

1. Antonova, O. Ie. (2005). Obdarovanist: dosvid istorychnoho ta porivnialnoho analizu: monohrafiia [Giftedness: the experience of historical and comparative analysis: Monograph]. Zhytomyr: Zhytomyrskyi derzhavnyi universytet imeni Ivana Franka. (ukr.).

2. Barko, V. (2000). Psykholoho-pedahohichna diahnostyka tvorchoho potentsialu osobystosti uchnia $v$ navalno-vykhovnomu protsesi [Psychological-pedagogical diagnostics of creative potential of the student's personality in the bulk-educational process]. Ternopil: TNU. (ukr.).

3. Borysiuk, A. S. (2016). Psykholohichni peredumovy y chynnyky osobystisnoho ta profesiinoho rozvytku studentiv [Psychological preconditions and factors of personal and professional development of students]. Chernivtsi: Tekhnodruk. (ukr.).

4. Bryl, M. M. (2011). Vplyv sotsiokulturnoho seredovyshcha na rozvytok kreatyvnosti studentiv [Influence of the socio-cultural environment on the development of students' creativity]. Aktualni problemy psykholohii [Actual problems of psychology], 10, 20, 22-30. (ukr.).

5. Volobuieva, T. B. (2015). Rozvytok tvorchoi kompetentnosti [Development of creative competence]. Kharkiv: KhNU. (ukr.).

6. Karpenko, Z. (2018). Aksiolohichna psykholohiia osobystosti: monohrafiia [Axiological psychology of personality: monograph]. Ivano-Frankivsk: DVNZ «Prykarpatskyi natsionalnyi universytet imeni Vasylia Stefanyka». (ukr.).

7. Klymeniuk, Yu.M. (2015). Obdarovani dity, yikh vyiavlennia ta diahnostyka [Gifted children, their detection and diagnostics]. Problemy osvity: zbirnyk naukovykh prats [Problems of education: a collection of scientific works]. Spetsvypusk. Vinnytsia-Kyiv, 46-50. (ukr.).

8. Kulchytska, O. (2007). Metodyka diahnostyky intelektualnoi obdarovanosti [Methodology of diagnostics of intellectual giftedness]. Obdarovana dytyna [Gifted child], 1, 39-42. (ukr.).

9. Leites, N. S. (1997). Vozrastnaia odarennost $i$ individualnye razlichiia [Age giftedness and individual differences]. M.: In-t prakt. psikhologii; Voronezh: NPO «MODEK». (rus.). 
10. Tkachenko, E. S. (2000). K voprosu o strukture odarennosti i yeyo kharakteristikakh [On the issue of the structure of giftedness and its characteristics]. Aktualnye problemy psikhologii, filosofii, etiki i estetiki [Actual problems of psychology, philosophy, ethics and aesthetics], 74-77. (rus.).

11. Tkachenko, E. S. (2003). Initsiativnost kak vedushchaia cherta lichnosti odarennogo podrostka [Initiative as a leading personality trait of a gifted teenager]. Psikhologiia otnoshenii i psikhicheskaia reguliatsiia deiatelnosti [Psychology of relations and mental regulation of activity], 116-119. (rus.).

\section{Natalya Dobrovolska \\ SYSTEM-INTEGRATED APPROACH TO THE PROBLEM OF PERSONALITY AT THE DIFFERENT STAGES OF ITS ONTOGENESIS}

The article describes the possibilities of applying the system-integrated approach to the study of the problem of gifted personality at various stages of its ontogenesis. In particular, from the standpoint of a systemintegrated approach, the general structure of psycho-regulating components of a gifted personality is revealed. The structure of social and psychological manifestations of gifted personality is considered and their contribution to the general regulation of educational activity is determined; the hierarchy of dominant values and motives of gifted teenagers is revealed and the typology of gifted children is revealed with the disclosure of the content and structural characteristics of each type; formulated psychodiagnostic criteria of personality characteristics that promote the regulation of educational activities and shows the importance of value orientations for optimal disclosure of talented gifted students; A special program of social and psychological support for the process of becoming a gifted person is developed. Individual differences in the components of mental regulation of educational activities allowed to select a group of gifted respondents with a productive motivational component of the psychological regulation of such activities and those with an unproductive motivational component of the psychological regulation of educational activity. It is shown that the implementation of a systematic approach in this field requires not only the reconstruction of existing concepts of giftedness, but also the development of new technological solutions - a set of tools that can capture the subject as multidimensional, holistic and changing in time, in particular depending on different learning conditions. The program of social and psychological support, based on the principles of the system-integrated approach and aimed at the formation of the motivational component of the mechanism of mental regulation of the educational activities of gifted personality, proved its effectiveness in increasing the indicators of creative motivation, creative orientation, reflexivity, the ability to combine, divergent thinking, freedom associations, ingenuity, self-esteem, self-regulation.

Keywords: personality, ontogenesis, giftedness, giftedness structure, system-integrated approach. 